\title{
Assessment of the Relative Vulnerabilities of Farmers due to Climate Change in Coastal Agriculture in Odisha
}

\author{
Nagma Halima Saik*, Bishnu Priya Mishra and Aditya Kumar Malla \\ College of Agriculture, OUAT, BBSR, India \\ *Corresponding author
}

Keywords

Adaptation,

Awareness,

Egalitarianism,

Fatalism,

Vulnerability

Article Info

Accepted:

15 January 2021

Available Online:

10 February 2021
Climate change is already affecting agriculture, with effects unevenly distributed across the world. As climate change continues to exert increasing pressure upon the livelihoods and agricultural sector of many developing and developed nations, a need exists to understand and prioritise at the sub national scale which areas and communities are most vulnerable. The present investigation was aimed at assessing the relative vulnerabilities of farmers due to climate change. The study was conducted in the Marsaghai and Dwitiyalaya village of Kendrapara district and Sanagbpur and Tirtol village of Jagatsinghpur district of Odisha state with a total sample size of 200. As this is a gender perspective research study, out of the total respondents 100 are men and 100 are women who are selected by the process of random selection. The relative vulnerability of farmers about climate change was assessed through a well-structured interview schedule by the process of personal interview and focus group discussions. $31 \%$ of men farmers and $36 \%$ of women farmers agree that they are dependent on the available natural resources for agriculture. Furthermore, 54\% of women respondents and $49 \%$ of men respondents are moderately vulnerable to climate extremities. Various reasons like less awareness and knowledge and more pressure of work and family make women more vulnerable to climate change. With giving special attention to them, awareness camps and adequate training programmes along with social protection programmes in that area can help them prepare, adapt and empower against climate extremities.

\section{Introduction}

Agriculture is the most fundamentally lifesustaining of all human activities. In low and middle income countries, nearly 3 billion people live in rural areas and of those, 2.5 billion people depend on agriculture for livelihood Climate change is already affecting agriculture, with effects unevenly distributed across the world. As climate change continues to exert increasing pressure upon the 
livelihoods and agricultural sector of many developing and developed nations, a need exists to understand and prioritise at the sub national scale which areas and communities are most vulnerable. Multifaceted climate change impacts on agriculture vary in different parts of the world and the overall picture is very complex in coastal areas. Low-lying agricultural land is highly vulnerable to severe soil salinity, storm surge, coastal erosion and stagnant flood water problems. Simultaneously, the rapid and overwhelming changes to the climatic environment and associated factors have intensified the vulnerability of agricultural production in coastal areas. Beginning in the early 1990s, scientific consultative groups commissioned by the United Nations, including the Intergovernmental Panel on Climate Change (IPCC), began to study the causes, likely impacts, and possible mitigations of climate change in a systematic way, assembling and sifting world scientific opinion to arrive at an informed consensus. The Intergovernmental Panel on Climate Change (IPCC) is considered to be the leading scientific international body for the assessment of climate change, and consequently the starting point for this paper is vulnerability as defined by the IPCC. According to the IPCC (2007) definition, vulnerability in the context of climate change is "the degree to which a system is susceptible to, and unable to cope with, adverse effects of climate change, including climate variability and extremes. Vulnerability is a function of the character, magnitude, and rate of climate change and variation to which a system is exposed, its sensitivity, and its adaptive capacity". Thus, agricultural vulnerability to climate change can, for example, be described in terms of exposure to elevated temperatures, the sensitivity of crop yields to the elevated temperature and the ability of the farmers to adapt to the effects of this exposure and sensitivity by, for example, planting crop varieties that are more heat-resistant or switching to another type of crop.

\section{Materials and Methods}

The study was conducted in the Marsaghai and Dwitiyalaya village of Kendrapara district and Sanagbpur and Tirtol village of Jagatsinghpur district of Odisha state with a total sample size of 200. As this is a gender perspective research study, out of the total respondents 100 are men and 100 are women. The men and women respondents are selected by the process of random selection. The respondents' awareness and perception about climate change was assessed through a wellstructured interview schedule by the process of personal interview. Vulnerability is the degree to which a system is susceptible to, and unable to cope with, adverse effects of climate change, including climate variability and extremes. For the purpose of the study, Vulnerability is operationally defined as the inability of individuals or social groups to cope up with or adapt to climate change induced stresses placed on their livelihoods and well-being. Climate change vulnerability assessments can, for example, vary with respect to the methodological approach (e.g. experimental, modelling, meta-analysis, survey-based), the integration of natural and social science, policy focus, time horizon (short- to long-term), spatial scale (farm, local, national, regional, global level), consideration of uncertainties, and the degree of stakeholder involvement. In this section, general methods applied for assessing vulnerability to climate change are highlighted, focusing briefly on the use of indicators, modelling approaches and stakeholder involvement. Over the past decade a growing number of vulnerability assessments have emerged from the scientific literature that focus on assessing the vulnerability of various sectors, including agriculture to climate change.

Considering the various individual and social 
dimensions, level of dependency on resources and other livelihood support systems an attempt was made to develop an index to measure vulnerability of men and women farmers. A composite vulnerability index was worked out drawing from the approaches of UNDP (2007).

As per that index, the respondents were categorized into highly, moderately and less vulnerable. Sub-indices like awareness and perception about climate change, level of dependency on natural and social capital, value orientation like fatalism and egalitarianism were worked out for each component of vulnerability. The values of each indicator were normalized to the range of values in the data set by applying the following formula.

Index Value

$=($ Actual Value - Minimum Value $)$

(Maximum Value - Minimum Value)

For the indicator with negative connotation, index value was reversed (1- index value). The overall index was formed from weighted average of the sub-indices, with the weights derived from theoretical understanding. The aggregated figure ranged from 0 to 1 , where 0 signified highest level of vulnerability.

The respective weights for sub-indices were drawn from literature and experts' opinion. The overall equation for the model employed for the study was:

$\mathrm{VI}={ }_{\mathrm{i}=1}^{\mathrm{n}} \sum\left(\mathrm{I}_{\mathrm{i}} * \mathrm{~W}_{\mathrm{i}}\right)$

$\mathrm{I}_{\mathrm{i}}=$ Sub-index and $\mathrm{W}_{\mathrm{i}}=$ Weights of the subindex.

$\mathrm{VI}=\mathrm{I}_{1} * 32.5+\mathrm{I}_{2} * 18.2+\mathrm{I}_{3} * 14.3+\mathrm{I}_{4} * 11.7+$ $\mathrm{I}_{5} * 23.4$

$\mathrm{I}_{1=}$ Awareness
$\mathrm{I}_{2}=$ Perception

$\mathrm{I}_{3=}$ Fatalism

$\mathrm{I}_{4}=$ Egalitarianism

$\mathrm{I}_{5}=$ Level of dependency

\section{Results and Discussion}

\section{Fatalism}

Fatalism was operationally described as "a philosophical doctrine holding that all events are predetermined in advance for all time and men and women are powerless to change them." Fatalism refers to believe in fate. People believe in fatalism generally due to lack of education where they attribute to the process and its outcome to the fate in any event. Fatalism was measured in a five point continuum where the subjects were asked to express their agreement and disagreement with a set of five statements drawn from the modified scale of Leiserowitz (2006).

The table 1 clearly indicates that about for about $48 \%$ of men farmer agree that future is too uncertain to make serious plans and about $46 \%$ of them agree that it did not make much of a difference whether they elect one political candidate or another. $38 \%$ of the men respondents agree to the statement that life is like a lottery and $47 \%$ of them agree that they are better off if they do not trust anyone. Majority of the respondents.i.e. $45 \%$ agree that they have very little control over their life.

For $49 \%$ of men respondents agree that there is no use in worrying about public affairs; as they cannot do anything about it anyway. 38\% of the men farmers disagree to the fact that women's life is more difficult and $48 \%$ of them agree that farmers' lives are more tougher. Affirmation with these statements by 
a majority of men farmers reveals prevalence of value of fatalism which retards the development process. It is very essential to bring about change in value orientation of men farmers to carry on to the path of progressiveness.

There should be sufficient trainings to train and motivate the farmers to take initiatives and to have control over the respective processes and outcomes. Farmers' knowledge, skill and attitude will be enhanced if they will be exposed to the climate resilient technologies.

About $37 \%$ of the women respondents strongly agree that future is too uncertain for a person to make serious plans and $49 \%$ of them agree to the statement that it does not make much of a difference if people elect one political candidate or another. $31 \%$ of the women farmers do not agree that life is like a lottery and $45 \%$ of them agree that it's better not to trust anyone.

Furthermore, $48 \%$ agree that they have very little control over their life and $49 \%$ of them agree that it is no use worrying about public affairs as they cannot do anything about them anyway.

A majority of the women respondents'.i.e. $56 \%$ agree that women's life is more difficult and $54 \%$ of them agree that farmers' lives are tougher. Affirmation with these statements by a majority of men farmers reveals prevalence of value of fatalism which retards the development process. It is very essential to bring about change in value orientation of men farmers to carry on to the path of progressiveness. There should be sufficient trainings to train and motivate the farmers to take initiatives and to have control over the respective processes and outcomes. Knowledge about modern technologies and drudgery reducing techniques can motivate the women farmers to work in a more productive way (Table 2).

\section{Egalitarianism}

Egalitarianism refers to value orientation to reality. It is measured with the five point continuum modified scale of (Leiserowitz, 2006). The obtained mean values of more than 4 for most of the statements amply indicate the affirmation of the majority of the men respondents about egalitarianism. 52\% of the men respondents agreed that we would have fewer problems if people were treated equally. Similarly the statement with negative connotation with respect to egalitarianism "We have gone too far in pushing equal rights" the mean score was 1.74 which indicates most of the respondents disagree to it. It can be assumed from the above mean score that a large majority of them held a high value of equality. This positive response is highly appreciable as it shows equal accessibility and distribution of common goods among the society. At the time of crisis such value of efforts will facilitate the efforts and approach of people in due to adverse effects of climate change.

Measured with the five point continuum modified scale of (Leiserowitz, 2006). The obtained mean values of more than 4 for most of the statements amply indicate the affirmation of the majority of the women respondents about egalitarianism. $48 \%$ of the women respondents agreed that we would have fewer problems if people were treated equally. Similarly the statement with negative connotation with respect to egalitarianism "We have gone too far in pushing equal rights" the mean score was 2.61 which indicate most of the respondents disagree to it. It can be assumed from the above mean score that a large majority of them held a high value of equality (Table 3 and 4). 
Table.1 Distribution of men farmer respondents according to value of Fatalism

\begin{tabular}{|c|c|c|c|c|c|c|}
\hline & & & & & \multicolumn{2}{|c|}{$(\mathrm{N}=100)$} \\
\hline Statements & $\begin{array}{c}\text { SA } \\
f(\%)\end{array}$ & $\begin{array}{c}\text { A } \\
f(\%)\end{array}$ & $\begin{array}{c}\text { UD } \\
f(\%)\end{array}$ & $\begin{array}{c}\mathrm{D} \\
f(\%)\end{array}$ & $\begin{array}{c}\text { SD } \\
f(\%)\end{array}$ & Mean \\
\hline $\begin{array}{l}\text { The future is too uncertain for a } \\
\text { person to make serious plans }\end{array}$ & 23 & 48 & 2 & 21 & 6 & 3.61 \\
\hline $\begin{array}{l}\text { Whether you elect one political } \\
\text { candidate or another, it does not } \\
\text { make much of difference. }\end{array}$ & 38 & 46 & $\mathbf{0}$ & 12 & 4 & 4.02 \\
\hline I feel that life is like a lottery & 36 & 38 & 3 & 15 & 8 & 3.79 \\
\hline $\begin{array}{l}\text { A person is better off if he or she } \\
\text { does not trust anyone. }\end{array}$ & 45 & 47 & $\mathbf{0}$ & 7 & 1 & 4.28 \\
\hline $\begin{array}{l}\text { I have very little control over my } \\
\text { life }\end{array}$ & 11 & 45 & 9 & 21 & 14 & 3.18 \\
\hline $\begin{array}{l}\text { It is no use worrying about } \\
\text { public affairs; I cannot do } \\
\text { anything about them anyway. }\end{array}$ & 39 & 49 & 1 & 9 & 2 & 4.14 \\
\hline $\begin{array}{l}\text { I feel women's life are more } \\
\text { difficult }\end{array}$ & 17 & 28 & 6 & 38 & 11 & 3.02 \\
\hline $\begin{array}{c}\text { I feel that farmers lives are more } \\
\text { tougher }\end{array}$ & 47 & 48 & 1 & 4 & $\mathbf{0}$ & 4.38 \\
\hline
\end{tabular}

(SA-Strongly Agree, A-Agree, UD-Undecided, D-Disagree, SD-Strongly Disagree $f$ - Frequency, \%-Percentage)

Table.2 Distribution of women farmer respondents according to value of Fatalism

\begin{tabular}{|c|c|c|c|c|c|c|}
\hline \multicolumn{1}{|c|}{ Statements } & $\begin{array}{c}\text { SA } \\
f(\%)\end{array}$ & $\begin{array}{c}\text { A } \\
f(\%)\end{array}$ & $\begin{array}{c}\text { UD } \\
f(\%)\end{array}$ & $\begin{array}{c}\text { D } \\
f(\%)\end{array}$ & $\begin{array}{c}\text { SD } \\
f(\%)\end{array}$ & Mean \\
\hline $\begin{array}{c}\text { The future is too uncertain for a } \\
\text { person to make serious plans }\end{array}$ & 37 & 32 & 7 & 20 & 4 & 3.78 \\
\hline $\begin{array}{c}\text { Whether you elect one political } \\
\text { candidate or another, it does not } \\
\text { make much of difference. }\end{array}$ & 39 & 49 & 2 & 9 & 1 & 4.16 \\
\hline $\begin{array}{c}\text { I feel that life is like a lottery } \\
\text { A person is better off if he or she } \\
\text { does not trust anyone. }\end{array}$ & 21 & 26 & 13 & 31 & 9 & 3.19 \\
\hline $\begin{array}{c}\text { I have very little control over my } \\
\text { life }\end{array}$ & 47 & 48 & 0 & 5 & 4 & 4.03 \\
\hline $\begin{array}{c}\text { It is no use worrying about } \\
\text { public affairs; I cannot do } \\
\text { anything about them anyway. }\end{array}$ & 48 & 49 & 1 & 2 & 0 & 4.37 \\
\hline $\begin{array}{c}\text { I feel women's life are more } \\
\text { difficult }\end{array}$ & 41 & 56 & 3 & 0 & 0 & 4.38 \\
\hline $\begin{array}{c}\text { I feel that farmers lives are more } \\
\text { tougher }\end{array}$ & 37 & 54 & 4 & 3 & 2 & 4.21 \\
\hline
\end{tabular}

(SA-Strongly Agree, A-Agree, UD-Undecided, D-Disagree, SD-Strongly Disagree

$f$-Frequency, \%-Percentage) 
Table.3 Distribution of men farmer respondents according to value of Egalitarianism

\begin{tabular}{|c|c|c|c|c|c|c|}
\hline & & & & \multicolumn{3}{|c|}{$(\mathrm{N}=100)$} \\
\hline Statements & $\begin{array}{c}\text { SA } \\
f(\%)\end{array}$ & $\begin{array}{c}\mathrm{A} \\
f(\%)\end{array}$ & $\begin{array}{c}\text { UD } \\
f(\%)\end{array}$ & $\begin{array}{c}\mathrm{D} \\
f(\%)\end{array}$ & $\begin{array}{l}\text { SD } \\
f(\%)\end{array}$ & Mean \\
\hline $\begin{array}{l}\text { What this world needs is a more equal } \\
\text { distribution of wealth }\end{array}$ & 34 & 47 & 3 & 12 & 4 & 3.95 \\
\hline $\begin{array}{c}\text { I support Government effort to get rid of } \\
\text { poverty }\end{array}$ & 25 & 53 & 2 & 15 & 5 & 3.78 \\
\hline I support affirmative action & 38 & 46 & 5 & 9 & 2 & 4.09 \\
\hline $\begin{array}{l}\text { Firms and Institutions should be so organized } \\
\text { that everybody can influence important } \\
\text { decisions }\end{array}$ & 18 & 42 & 16 & 15 & 9 & 3.45 \\
\hline $\begin{array}{l}\text { If people were treated more equally we would } \\
\text { have fewer problems }\end{array}$ & 45 & 52 & $\mathbf{0}$ & 3 & $\mathbf{0}$ & 4.39 \\
\hline $\begin{array}{l}\text { The world would be a more peaceful place if } \\
\text { its wealth were divided more equally among } \\
\text { nations. }\end{array}$ & 39 & 42 & 6 & 10 & 3 & 4.04 \\
\hline We have gone too far in pushing equal rights & 8 & 2 & $\mathbf{0}$ & 48 & 42 & 1.74 \\
\hline $\begin{array}{l}\text { If men and women were treated more equally } \\
\text { we would have a more improved and balanced } \\
\text { society }\end{array}$ & 32 & 39 & 1 & 25 & 3 & 3.72 \\
\hline $\begin{array}{l}\text { If wealth and other productive resources were } \\
\text { equally distributed among men and women } \\
\text { there would be more prosperity. }\end{array}$ & 21 & 35 & 3 & 31 & 7 & 3.23 \\
\hline
\end{tabular}

(SA-Strongly Agree, A-Agree, UD-Undecided, D-Disagree, SD-Strongly Disagree

$f$ - Frequency, \%-Percentage)

Table.4 Distribution of women farmer respondents according to value of Egalitarianism

\begin{tabular}{|c|c|c|c|c|c|c|}
\hline & & & & \multicolumn{3}{|c|}{$(\mathrm{N}=100)$} \\
\hline Statements & $\begin{array}{c}\text { SA } \\
f(\%)\end{array}$ & $\begin{array}{c}\mathrm{A} \\
f(\%)\end{array}$ & $\begin{array}{c}\text { UD } \\
f(\%)\end{array}$ & $\begin{array}{c}\mathrm{D} \\
f(\%)\end{array}$ & $\begin{array}{c}\text { SD } \\
f(\%)\end{array}$ & Mean \\
\hline $\begin{array}{l}\text { What this world needs is a more equal distribution } \\
\text { of wealth }\end{array}$ & 14 & 37 & 11 & 20 & 18 & 3.09 \\
\hline I support Government effort to get rid of poverty & 35 & 41 & 4 & 16 & 4 & 3.87 \\
\hline I support affirmative action & 32 & 41 & 5 & 17 & 5 & 3.78 \\
\hline $\begin{array}{l}\text { Firms and Institutions should be so organized that } \\
\text { everybody can influence important decisions }\end{array}$ & 18 & 25 & 19 & 21 & 17 & 3.06 \\
\hline $\begin{array}{l}\text { If people were treated more equally we would have } \\
\text { fewer problems }\end{array}$ & 48 & 46 & $\mathbf{0}$ & 6 & $\mathbf{0}$ & 4.36 \\
\hline $\begin{array}{l}\text { The world would be a more peaceful place if its } \\
\text { wealth were divided more equally among nations. }\end{array}$ & 51 & 49 & $\mathbf{0}$ & $\mathbf{0}$ & $\mathbf{0}$ & 4.51 \\
\hline We have gone too far in pushing equal rights & 24 & 35 & 6 & 26 & 9 & 2.61 \\
\hline $\begin{array}{l}\text { If men and women were treated more equally we } \\
\text { would have a more improved and balanced society }\end{array}$ & 42 & 53 & 1 & 4 & $\mathbf{0}$ & 4.33 \\
\hline $\begin{array}{l}\text { If wealth and other productive resources were } \\
\text { equally distributed among men and women there } \\
\text { would be more prosperity. }\end{array}$ & 46 & 48 & $\mathbf{0}$ & 5 & 1 & 4.33 \\
\hline
\end{tabular}

(SA-Strongly Agree, A-Agree, UD-Undecided, D-Disagree, SD-Strongly Disagree

$f$ - Frequency, \%-Percentage) 
Table.5 Distribution of men farmer respondents on the basis of their level of dependency

\begin{tabular}{|c|c|c|c|c|c|c|}
\hline \multirow{4}{*}{ Statements } & \multicolumn{6}{|c|}{$(\mathrm{N}=100)$} \\
\hline & \multicolumn{5}{|c|}{$\begin{array}{l}\text { level of dependency of Men } \\
\qquad(N=100)\end{array}$} & \multirow[t]{3}{*}{ Mean } \\
\hline & SA & $\mathbf{A}$ & UD & D & SD & \\
\hline & $\underset{(\%)}{f}$ & $\underset{(\%)}{f}$ & $\underset{(\%)}{f}$ & $\underset{(\%)}{f}$ & $\underset{(\%)}{f}$ & \\
\hline Income Sources & 39 & 37 & 5 & 13 & 6 & 3.90 \\
\hline Educational Qualification & 26 & 45 & 2 & 20 & 7 & 3.63 \\
\hline $\begin{array}{c}\text { Available Resources(Natural, physical, } \\
\text { Social) }\end{array}$ & 16 & 31 & 23 & 17 & 13 & 3.20 \\
\hline Exposure to climate change & 43 & 33 & 4 & 18 & 2 & 3.97 \\
\hline Social variable & 28 & 29 & 12 & 25 & 6 & 3.48 \\
\hline Communication variable & 24 & 38 & 3 & 26 & 9 & 3.42 \\
\hline Lack of Infrastructure & 49 & 45 & $\mathbf{0}$ & 6 & $\mathbf{0}$ & 4.37 \\
\hline Lack of warning system & 32 & 43 & 7 & 12 & 6 & 3.83 \\
\hline Lack of Knowledge & 21 & 46 & $\mathbf{0}$ & 13 & 20 & 3.35 \\
\hline Lack of sense of empowerment & 12 & 34 & 15 & 26 & 13 & 2.94 \\
\hline
\end{tabular}

(SA-Strongly Agree, A-Agree, UD-Undecided, D-Disagree, SD-Strongly Disagree $f$-Frequency, \%-Percentage)

Table.6 Distribution of women farmer respondents on the basis of their level of dependency

$(\mathrm{N}=100)$

\begin{tabular}{|c|c|c|c|c|c|c|}
\hline \multirow[t]{3}{*}{ Statements } & \multicolumn{5}{|c|}{$\begin{array}{l}\text { Level of dependency of Women } \\
\qquad(N=100)\end{array}$} & \multirow[t]{3}{*}{ Mean } \\
\hline & SA & A & UD & D & SD & \\
\hline & $\underset{(\%)}{f}$ & $\underset{(\%)}{f}$ & $\underset{(\%)}{f}$ & $\underset{(\%)}{f}$ & $\underset{(\%)}{f}$ & \\
\hline Income Sources & 33 & 49 & 7 & 9 & 2 & 4.02 \\
\hline Educational Qualification & 32 & 35 & 13 & 11 & 9 & 3.70 \\
\hline $\begin{array}{c}\text { Available Resources(Natural, physical, } \\
\text { Social) }\end{array}$ & 29 & 36 & 18 & 7 & 10 & 3.67 \\
\hline Exposure to climate change & 36 & 42 & 5 & 10 & 7 & 3.90 \\
\hline Social variable & 55 & 41 & 1 & 3 & $\mathbf{0}$ & 4.48 \\
\hline Communication variable & 43 & 39 & 2 & 15 & 1 & 4.08 \\
\hline Lack of Infrastructure & 37 & 48 & 6 & 7 & 2 & 4.11 \\
\hline Lack of warning system & 16 & 34 & 18 & 22 & 10 & 3.24 \\
\hline Lack of Knowledge & 38 & 47 & 5 & 10 & $\mathbf{0}$ & 4.13 \\
\hline Lack of sense of empowerment & 28 & 46 & 11 & 13 & 2 & 2.15 \\
\hline
\end{tabular}

(SA-Strongly Agree, A-Agree, UD-Undecided, D-Disagree, SD-Strongly Disagree $f$ - Frequency, \%- Percentage) 
Table.7 Distribution of men farmer respondents according to their level of vulnerability

\begin{tabular}{|c|c|c|}
\hline $\begin{array}{c}\text { Vulnerability Index } \\
\text { Intervals }\end{array}$ & Frequency $(\boldsymbol{f})$ & Percentage (\%) \\
\hline Highly vulnerable $(<.383)$ & 20 & 20 \\
\hline $\begin{array}{c}\text { Moderately vulnerable } \\
(.383-.329)\end{array}$ & 49 & 49 \\
\hline Less vulnerable $(>.291)$ & 31 & 31 \\
\hline
\end{tabular}

Table.8 Distribution of women farmer respondents according to their level of vulnerability

\begin{tabular}{|c|c|c|}
\hline \multicolumn{2}{|c|}{$(\mathrm{N}=100)$} \\
\hline $\begin{array}{c}\text { Vulnerability Index } \\
\text { Intervals }\end{array}$ & Frequency $(\boldsymbol{f})$ & Percentage $(\%)$ \\
\hline Highly vulnerable $(<.379)$ & 37 & 37 \\
\hline $\begin{array}{c}\text { Moderately vulnerable } \\
(.379-\text {.326) }\end{array}$ & 54 & 54 \\
\hline Less vulnerable $(>.230)$ & 9 & 9 \\
\hline
\end{tabular}

This positive response is highly appreciable as it shows equal accessibility and distribution of common goods among the society. At the time of crisis such value of efforts will facilitate the efforts and approach of people in due to adverse effects of climate change.

The table 5 indicates that $39 \%$ of the men respondents strongly agree to the fact that their income depends on farming and majority of them $(45 \%)$ agree that to have knowledge about climate change, education is needed. $31 \%$ farmers agree that they are dependent on available resources and $49 \%$ of them strongly agree that infrastructural facilities are needed to store the harvest products and livestock properly. $43 \%$ agree that there is lack of warning system and $34 \%$ agree that people lack the sense of empowerment in that area. Hence, people need to be educated to have knowledge about climate change reasons and risks involved in these and to self motivate themselves to be empowered. Knowledge earning can also help them in judicious use of natural and available resources for sustainable use. Also they need to be sensitized for building up social capital with networking, reciprocity and linkage for better cohesiveness and collective action for better preparedness and adaptation for climate change crises.

The table 6 indicates that $49 \%$ of the women respondents strongly agree to the fact that their income depends on farming and 35\% agree that to have knowledge about climate change, education is needed. $36 \%$ women farmers agree that they are dependent on available resources and $48 \%$ of them strongly agree that infrastructural facilities are needed to store the harvest products and livestock properly. 34\% agree that there is lack of warning system and $46 \%$ agree that people lack the sense of empowerment in that area. Hence, people need to be educated to have knowledge about climate change reasons and risks involved in these and to self motivate themselves to be empowered. Knowledge earning can also help them in judicious use of natural and available resources for sustainable use. Also they need to be sensitized for building up social capital with networking, reciprocity and linkage for better cohesiveness and collective action for better preparedness and adaptation for climate change crises. From table 7 it is clearly seen that, most of the men respondents' i.e. $49 \%$ belong to moderately vulnerable followed by $31 \%$ were in less vulnerable group and $20 \%$ of them were highly vulnerable category. 
Majority of the men farmers in that area were having moderate level knowledge and awareness regarding risks and uncertainties relating to climate change which clears the fact that they have less knowledge and skill to climate change adaptation measures.

So there is need to arrange adequate awareness campaigns and training programmes in the area to empower them for better preparedness and adaptation of farmers to climate change extremities.

It is evident from table 8 that majority of the women respondents (54\%) belong to the moderately vulnerable group followed by $37 \%$ belonging to highly vulnerable and only $9 \%$ of them are of less vulnerable group. As compared to men farmers, women farmers are more vulnerable to climate change extremities.

Various reasons like less awareness and knowledge and more pressure of work and family make them more vulnerable to climate change. With giving special attention to them, awareness camps and adequate training programmes along with social protection programmes in that area can help them prepare, adapt and empower against climate extremities.

Majority of the women farmers are more vulnerable to climate extremities as compared to men farmers.

More percentage of women is may be due to lack of knowledge and awareness about climate change, adaptation skills, more load of work and lack of sense of empowerment. To develop adaptation strategies among women farmers, it is necessary to give special emphasis on sociopsychological empowerment of farmers. To do it, women farmers must be given psychological, motivational, and attitudinal and infrastructural support which will help in developing their capabilities for better adaptive mechanisms along with developing their competency skills. Their adaptive capacity must be strengthened in a holistic and productive manner.

\section{References}

Agriculture and climate change Challenges and opportunities at the global and local level Collaboration on Climate-Smart Agriculture, Food and Agriculture Organization of the United Nations Rome, 2019.

Climate Change, Agriculture, Water, and Food Security: What We Know and Don't Know, Massachusetts Institute of Technology

Climate Change Adaptation in Indian Agriculture- Assessing Farmers' Perception and Adaptive Choices, Jha CK, Gupta V, Research Gate

Daleen KV, Jung L, Dhatt R, Phelan AL. Climate Change and Gender based Health

Gregor Mac, Sherilyn. "A Stranger Silence Still: The Need for Feminist Social Research on Climate Change." The Sociological Review 57 (2010): 124-140. Web. 25 Oct. 2014.

Pasupalak S, Climate Change and Agriculture in Orissa,, Orissa Review, April-May 2009

Reddy J, Women Role In Agriculture, Aquaculture, Livestock., Agri Farming

Voicing Silence - Experience of Women with Disasters in Orissa, OSDMA, 2002/ page -3

\section{How to cite this article:}

Nagma Halima Saik, Bishnu Priya Mishra and Aditya Kumar Malla. 2021. Assessment of the Relative Vulnerabilities of Farmers due to Climate Change in Coastal Agriculture in Odisha. Int.J.Curr.Microbiol.App.Sci. 10(02): 1638-1646. doi: https://doi.org/10.20546/ijcmas.2021.1002.194 